\title{
EFFECT OF POMEGRANATE JUICE CONSUMPTION ON LIPID PROFILE IN HEALTHY AND HYPERCHOLESTEROLEMIC RATS
}

Abdullah M. Thannoun Maeda M. Tayib

Food Science Department, College of Agriculture and Forestry/ Mosul University/ Iraq.

E-mail: dr_thannoun@yahoo.Com

\begin{abstract}
Effect of pomegranate (Punica granatum L.) juice extracted by squeezing and centrifugation methods on lipids profile in healthy and induced hypercholesterolemic rats was investigated. Eighty adult male Sprague Dawley derived rats were individually housed in stainless steel cages having wires mesh bottoms and fronts in room maintained at $25-30{ }^{\circ} \mathrm{C}$, and light between 7:0 AM and 7:0 PM daily. Animals were randomly divided into two groups of forty animals, first group was undertaken to be the normal animals and the second group of other forty animals were fed on $4 \%$ cholesterol diet (Tables 1 and 2) before starting the experiment and fed 2\% cholesterol diet through the experiments. Each group was divided into eight subgroups related to seven pomegranate juices and control, five each and fed the diets for 28 days. The rats were daily gavaged with $1 \mathrm{ml}$ pomegranate juice after feeding except those of control groups giving $1 \mathrm{ml}$ distilled water. Lipids profile was measured at the beginning and at the termination of the experiment the rats were decapitated and blood was taken from the animals to measure again the above parameters. Results show that consumption of different pomegranate juices by healthy and hypercholesterolemic rats significantly $(\mathrm{P}<0.05)$ decreased TG, TC, LDL-C, TC/HDL-C and LDL-C/HDL-C and increased HDL-C values compared with control groups. In conclusion, pomegranate juice showed lipid-lowering effects in healthy and experimentally induced hypercholesterolemia rats, and could be requisite in reducing lipidemia as a factor of atherosclerosis risk.

Keywords: Atherogenic factor, Extraction methods, Lipid profile, Pomegranate juice, Rats.
\end{abstract}

Received: 18/6/2012 Accepted 10/9/2012.

\section{INTRODUCTION}

Pomegranate (Punica granatum L.) tree is widely cultivated around the world and native of the area of Middle East, including Iran to the Himalaya of India, and has been cultivated in Arabia, Turkey and over the entire Mediterranean region since ancient times ( Aviram et al., 2000; Aarabi et al., 2008 and Eksi and Özhamamc, 2009). It has been ennobled and sanctified by Islamic, Greek, Hebrews, Babylonians, Persians and Chinese (Aviram et al., 2000 and Viuda-Martos et al., 2010a). The edible part of pomegranate fruits is consumed fresh and the juices used to make jellies, puddings, desserts, drinks and flavoring in some beverages (Fadavi et al., 2005 and Viuda-Martos et al., 2010b).

The edible part of pomegranate fruits includes the arils and its juicy translucent flesh covering the seed. The edible portion (about $50 \%$ of total fruit weight) is composed of juicy seeds (arils) that comprise $80 \%$ juicy flesh and $20 \%$ seeds (Aviram

The research is a part of Thesis of second author. 
et al., 2000). Fresh pomegranate juice is a good source of nutrients such as sugars (i.e. fructose and glucose), pectin, organic acids (such as ascorbic, citric, malic, oxalic and tartaric acids), and minerals (mainly calcium, iron, zinc and potassium) (El-Nmer et al., 1990 and Viuda-Martos et al., 2010a). Pomegranate juice (PJ) is a rich source of potent polyphenolic, flavonoid antioxidants (anthocyanins), ellagitannins, and ellagic and gallic acid derivatives which have attracted much interest due to their important health benefits (Aviram et al., 2002; Clifford and Scalbert, 2000; Gil et al., 2000 and El kar et al.,2011). Recently many studies are highly praising the potential health benefits of the juice, seeds and their oil and even the peels of the pomegranate. So, this tree with all its parts contains all these beneficial substances that have proven antioxidant, antidiabetic, antiviral, antimicrobial, antiinflammatory and antitumoral activities (Jurenka, 2008 and Viuda-Martos et al., 2010a) and can be effective to assist in improving lipid profiles in diabetic patients with hyperlipidemia (Esmaillzadeh et al., 2004). Other studies have described it's abilities to prevent, inhibit, reduce and even destroy cancer cells (Lansky and Newman, 2007 and Malik et al., 2005). Consumption of pomegranate juice possesses anti-atherosclerotic properties which could be related to its potent anti-oxidative characteristics (Aviram and Dornfeld, 2001) and improve stress-induced myocardial ischemia in patients with Coronary Heart Disease (Sumner et al., 2005). In animals, pomegranate juice supplementation to mice with advanced atherosclerosis reduced their macrophage oxidative stress, their macrophage cholesterol flux and even attenuated the development of atherosclerosis (Kaplan et al., 2001). The aim of this study was to investigate the effect of pomegranate juice extracted by squeezing and centrifugation methods on lipid profile in normal and induced hypercholesterolemic rats.

\section{MATERIALS AND METHODS}

Pomegranate fruits source: Pomegranate fruits (Punica granatum L.,) were obtained from Armishy village in Zakho/ Northern of Iraq and this species of pomegranate is characterized by small arils and has three varieties classified according to its taste as follows: Sour, Sweet and Sour-Sweet pomegranate. Local pomegranate juice was obtained from local markets. Pomegranate Juice was extracted according to the method followed by Thannoun and Tayib (in press) which was modified from Miguel et al. (2004).

Chemical Analysis was performed as followed: Moisture was determined according to the method mentioned in Anonymous (2000) using electric vacuum oven made by Memmert Company at $105^{\circ} \mathrm{C}$ and $100 \mathrm{mmHg}$ pressure. Protein was determined by Macrokjeldahl method using technique mentioned in Anonymous (2000). Fat was determined by Soxhlet apparatus using method mention in Anonymous (2000). Fibers were determined using method mentioned in Anonymous (2000). Ash was determined according to method mentioned in Anonymous (2000) using Muffle Furnace made by Thermolyn Company at $550^{\circ} \mathrm{C}$ overnight or to complete ashing by obtaining white ash. However, carbohydrates were calculated by difference. Ascorbic acid (vitamin C) was determined according to the method mention by Anonymous (2000) using 2,6 dichloro phenol Indophenol dye.

Diet preparation: The diets were formulated according to Anonymous (1978) (Table1). The amount of dietary protein, fat, cellulose, sucrose, vitamins and minerals were formulated to be similar in all diets by adjusting the level of nutrients added. Cholesterol was added to a basal diet to provide 2 and $4 \%$ cholesterol diets other than 
original basal diet to feed the induced hypercholesterolemic rats before (4\%) and through the experimental time (2\%). Diet ingredients were thoroughly mixed in a mixer bowl by a mechanical mixer. The composition of the experimental diets is shown in Table (2). Experimental animals: Eighty adult male Sprague Dawley derived rats (Their parent were originally obtained from biology department, College of Science, Duhok University) were individually housed in stainless steel cages having wires mesh bottoms and fronts in room maintained at $25-30{ }^{\circ} \mathrm{C}$, and light between 7:0 AM to 7:0 PM daily. Animals were randomly divided into two groups of forty animals, the first one was undertaken to be the normal animals and the second group of other forty animals were fed on $4 \%$ cholesterol diet (Tables 1 and 2) before starting the experiment and fed $2 \%$ cholesterol diet through the experiments. Each group was divided into eight subgroups related to seven pomegranate juices and control, five each and fed the diets for 28 days. Food and distilled water were provided ad libitum. The rats were daily gavaged with $1 \mathrm{ml}$ pomegranate juice (The analysis of the pomegranate juices used in this study was performed and published in our previous study (Thannoun and Tayib, in press) after feeding except those of control groups giving $1 \mathrm{ml}$ distilled water. The animals' body weight and food scrap were weighted and measured and weighted once a week. Lipids profile was measured at the beginning of the experiment and at the termination the rats were decapitated and blood was taken from the animals to measure again the above parameters.

Table (1): Chemical component of diet mixtures (estimated) $(\mathrm{g} / 100 \mathrm{~g})$

\begin{tabular}{|l|c|c|c|c|c|c|c|c|c|}
\hline Diet & Cholesterol & Casein & $\begin{array}{c}\text { Corn } \\
\text { Oil }\end{array}$ & Sucrose & Cellulose & $\begin{array}{c}\text { Vitamins } \\
\text { Mix. }^{1}\end{array}$ & $\begin{array}{c}\text { Minerals } \\
\text { Mix. }\end{array}$ & $\mathrm{CaCO}_{3}$ & Starch \\
\hline Basal & 0.0 & 12 & 10 & 10 & 5 & 2 & 1.2 & 0.5 & 59.3 \\
\hline $\begin{array}{l}2 \% \\
\text { Cholesterol }\end{array}$ & 2 & 12 & 10 & 10 & 5 & 2 & 1.2 & 0.5 & 57.3 \\
\hline $\begin{array}{l}4 \% \\
\text { Cholesterol }\end{array}$ & 4 & 12 & 10 & 10 & 5 & 2 & 1.2 & 0.5 & 55.3 \\
\hline
\end{tabular}

1 The Vitamins mixture contained (G/kg): Vitamin A (retinyl acetate) 20000000 IU; Vitamin D3 (calciferol) 5000000 IU; $\alpha$ - Tocopherol 4 000; Thiamine hydrochloride 1.0; Riboflavin 4.0; Pyridoxal hydrochloride 3.0; Niacin 10.0; Folic acid 0.5; Calcium pantothenate 5.0; Vitamin B12 0.005; Choline hydrochloride 75; Ascorbic acid 45; Biotin 0.02; Menadoine 1.25 and starch to make $1 \mathrm{~kg}$ mixture.

2 The Minerals mixture contained (g/kg): FeSO4.7H2O 3.5; CaCO3 280; NaH2PO4 360; KCl 76; ZnSO4 0.2; MnSO4.H2O 2.0; CuSO4 4.0; KI 0.08; MgCO3 28 and starch to make $1 \mathrm{~kg}$ mixture.

Table (2): Chemical composition of balanced diets (determined) $(\mathrm{g} / 100 \mathrm{~g})$.

\begin{tabular}{|l|c|c|c|c|c|c|c|}
\hline Diet & moisture & protein & fat & fibers & Ash & Carbohydrate* & $\begin{array}{c}\text { Energy } \\
\text { Kcal/100g }\end{array}$ \\
\hline Basal & 12.5 & 11.62 & 9.93 & 4.85 & 1.9 & 59.3 & 372 \\
\hline $\begin{array}{l}2 \% \\
\text { Cholesterol }\end{array}$ & 12.1 & 11.25 & 12.25 & 5.0 & 1.9 & 57.3 & 386 \\
\hline $\begin{array}{l}4 \% \\
\text { cholesterol }\end{array}$ & 12.4 & 11.32 & 13.83 & 4.7 & 2.45 & 55.3 & 391 \\
\hline
\end{tabular}

*by difference. Numbers are average of three samples. 
Biochemical Analysis: Glucose in the serum was determined using special Kit produced by Com Tech Medical (UK). The concentration of total cholesterol diets was determined according to the procedure followed by Tietz (1987) which was a modification of the Liberman-Buchared reaction after a modified Folch extraction of lipids (Folch et al. 1957). The extracted lipid from the samples were weighed and dissolved in $10 \mathrm{ml}$ chloroform and $1 \mathrm{ml}$ was used for the reaction. Reference cholesterol was obtained from Sigma chemical Co. (St. Louis, MO, USA). Total cholesterol and lipoproteins concentrations of serum was determined according to the modified method of Plummer (1978) and using special Kits made by international company for medical indicator (Diamind, Jordan). Triglycerides were determined by special Kits made by Giess, Dia Gnostics-Italy. HDL-c was determined using special Kits made by Spinreact SA Company (Spain). LDL- $\mathrm{c}$ and VLDL-c were calculated according to equation mentioned by Glew and Peters (1987).

Statistical Analysis: Data were analyzed by one way analysis of Variance and Standard deviations were calculated by using Duncan's Multiple Range Test (Steel and Torrie, 1980).

\section{RESULTS AND DISCUSSION}

The effect of pomegranate juice extracted by squeezing and centrifugation methods on lipid profile in healthy rats was shown in Table (3). The data show that there were significant $(\mathrm{p}<0.05)$ differences between Triglycerides $(\mathrm{TG})$ levels of animals gavaged pomegranate juice after 28 days of experiments. The level of TG ranged between the lowest values of $42.66 \mathrm{mg} / 100 \mathrm{ml}$ for rats gavaged with Sour-sweet/ squeezing juice to highest value of $58.83 \mathrm{mg} / 100 \mathrm{ml}$ for group of animals gavaged with sour pomegranate juice extracted by centrifugation method. However, comparing the levels of TC after 28 days of experiment sowed that they were decreased in all groups of animals gavaged with pomegranate juices compared with control group. Results show that clear reduction was observed in which the TG level was decreased from 73.37 to 57.91 $\mathrm{mg} / 100 \mathrm{ml}$ in animals gavaged with sour pomegranate juice extracted by squeezing method and from 61.5 to $45.8 \mathrm{mg} / 100 \mathrm{ml}$ in animals gavaged with sweet pomegranate juice extracted by squeezing method and followed by animals gavaged with sour sweet pomegranate juice extracted by squeezing, then animals gavaged with sweet pomegranate juice extracted by centrifugation and finally animals gavaged with sour sweet pomegranate juice extracted by centrifugation method, however, the reduction was from 64.18 to $50.01 \mathrm{mg} / 100 \mathrm{ml}$ in animals gavaged with commercial pomegranate juice.

Results in Table (3) show that there were a significant $(\mathrm{p}<0.05)$ differences between total cholesterol (TC) levels in the serum of healthy animals fed basal diet and daily gaveging with pomegranate juices for 28 days and with those of control animals. The TC levels for all groups were decreased after treatment with pomegranate juice. The highest level of cholesterol were 67.6 and $67.24 \mathrm{mg} / 100 \mathrm{ml}$ for groups of animals gavaged with sour sweet pomegranate juices extracted by centrifugation and squeezing methods, respectively and these were not differed significantly $(\mathrm{P}<0.05)$ than TC level $(64,99 \mathrm{mg} / 100 \mathrm{ml})$ of group of animals gaveged with commercial pomegranate juice. While the lowest level of TC was $42.61 \mathrm{mg} / 100 \mathrm{ml}$ of group of animals gaveged with sweet/ squeezing compared with $63.6 \mathrm{mg} / 100 \mathrm{ml}$ for control animals and this was almost similar to TC level of animals gavaged with sweet pomegranate juice extracted by centrifugation in which there was no significant difference between them. When the 
levels of TC had been compared after 28 days of experiment showed that they were decreased in all groups of animals gavaged with pomegranate juices compared with control group. However, the level of TC for control group was changed slightly from 62.5 to $63.6 \mathrm{mg} / 100 \mathrm{ml}$ while data indicated that TC levels of animals gavaged with sour pomegranate juice extracted by squeezing method was reduced from 52.29 to 45.4 $\mathrm{mg} / 100 \mathrm{ml}$. The lowest reduction in TC level was for animals gavaged with sweet pomegranate extracted by centrifugation method $(68.4$ to $62.1 \mathrm{mg} / 100 \mathrm{ml})$. Lower reduction in TC was shown by commercial pomegranate compared with groups gavaged with other pomegranate juices. This reduction of TC levels as affected by gvaging with pomegranate juices may be due to the effect of antioxidant activity of phenolic and other active compounds found in pomegranate juice and this would protect fat oxidation in which prevent the atherosclerosis progress (Bors, 1999 and Elzbieta, 2000)

Table (3) also shows that there were no significant $(p<0.05)$ differences between the high density lipoprotein cholesterol (HDL-C) in healthy animals gavaged with all pomegranate juices and after 28 days. The levels of HDL-C ranged between 13.09 in animals gavaged with sweet pomegranate extracted by centrifugation method to 15.33 $\mathrm{mg} / 100 \mathrm{ml}$ in animals gavaged with commercial pomegranate juice. Comparing the levels of HDL-C after 28 days of experiment showed that they were increased in all groups of animals gavaged with pomegranate juices compared with control group. It has been noticed that the most valuable juice in increasing the HDL-C was sour sweet pomegranate juice extracted by squeezing method in which the level of HDL-C was increased from 11.87 to $13.66 \mathrm{mg} / 100 \mathrm{ml}$, however the lowest increase was in animals gavaged with commercial pomegranate juice in which increased the level from 15.12 to $15.33 \mathrm{mg} / 100 \mathrm{ml}$.

The data in Table (3) also show that there were a significant $(\mathrm{P}<0.05)$ differences between the value of low density lipoproteins (LDL-C) in animals gavaged with all pomegranate juices after 28 days of experiment. The levels of LDL-C was ranged between $19.94 \mathrm{mg} / 100 \mathrm{ml}$ in animals gavaged with sweet pomegranate juice extracted by squeezing method and $45.06 \mathrm{mg} / 100 \mathrm{ml}$ in animals gavaged with sour sweet pomegranate juice extracted by sqeezing method. Comparing the levels of LDL-C after 28 days of experiment we found that the levels were decreased for all the groups of animals gavaged with pomegranate juices compared with control group. The level of LDL-C was decreased from 35.23 to $20.05 \mathrm{mg} / 100 \mathrm{ml}$ in animals gavaged with sour pomegranate juice extracted by squeezing method, while the level was decreased from 43.07 to $38.07 \mathrm{mg} / 100$ $\mathrm{ml}$ in animals gavaged with sweet pomegranate juice extracted by centrifugation compared with control animals in which the LDL-C level was increased slightly from 73.01 to 37.52 $\mathrm{mg} / 100 \mathrm{ml}$.

The reduction in TG, TC, LDL-C and increased the HDL-C in animals gavaged with all pomegranate juices are considered as improvement factor of lipid profile compared with control group. These results were in agreement with those found by Yousif (2000). The improvement of lipid profile toward reduction of serum lipids specially cholesterol and 
Mesopotamia J. of Agric.

Vol. (42) No. (1) 2014
ISSN: 2224-9796 (Online)

ISSN: 1815-316 X (Print)
مجـلـة زر اعــة الر افديـن

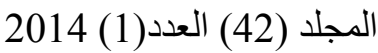

Table (3): Effect of pomegranate juice extracted by squeezing and centrifugation methods on lipid profile in healthy rats $(\mathrm{mg} / 100 \mathrm{ml})$.

\begin{tabular}{|c|c|c|c|c|c|c|c|c|c|c|c|c|}
\hline \multirow{2}{*}{ juice Profile } & \multicolumn{2}{|l|}{ TG } & \multicolumn{2}{|l|}{$\mathrm{TC}$} & \multicolumn{2}{|l|}{ HDL-c } & \multicolumn{2}{|l|}{ LDL-c } & \multicolumn{2}{|c|}{ TC/HDL-c } & \multicolumn{2}{|c|}{ LDL-c/HDL-c } \\
\hline & Initial & Final & Initial & Final & Initial & Final & Initial & Final & Initial & Final & Initial & Final \\
\hline Control & $69.3 \quad \mathrm{a}$ & $58.22 \mathrm{a}$ & $62.5 \quad \mathrm{c}$ & $63.6 \mathrm{abc}$ & $13.63 \mathrm{~b}$ & $13.78 \mathrm{~b}$ & $37.01 \mathrm{c}$ & $38.53 \mathrm{abc}$ & $4.22 \mathrm{f}$ & $2.58 \mathrm{c}$ & $2.03 \mathrm{~d}$ & $0.72 \mathrm{~d}$ \\
\hline $\begin{array}{l}\text { Sour/ } \\
\text { squeezing }\end{array}$ & $73.37 \mathrm{a}$ & $57.91 \quad \mathrm{a}$ & $62.29 \mathrm{c}$ & $45.413 \mathrm{~d}$ & $12.39 \mathrm{~cd}$ & $13.78 \mathrm{~b}$ & $35.23 \mathrm{c}$ & $20.05 \mathrm{~d}$ & $4.22 \mathrm{f}$ & $2.58 \mathrm{c}$ & $2.03 \mathrm{~d}$ & $0.72 \mathrm{~d}$ \\
\hline $\begin{array}{l}\text { Sour/ } \\
\text { centrifugation }\end{array}$ & $72.01 \mathrm{a}$ & $58.83 \mathrm{a}$ & $72.43 \quad \mathrm{a}$ & $57.372 \mathrm{bc}$ & $12.86 \mathrm{c}$ & $14.06 \mathrm{~b}$ & $45.52 \mathrm{bc}$ & $31.55 \mathrm{c}$ & $5.64 \mathrm{~cd}$ & $4.12 \mathrm{~b}$ & $3.55 \mathrm{c}$ & $2.29 \mathrm{~b}$ \\
\hline $\begin{array}{l}\text { Sour-sweet/ } \\
\text { squeezing }\end{array}$ & $67.0 \quad \mathrm{a}$ & $42.66 \mathrm{c}$ & $74.52 \mathrm{a}$ & $67.242 \mathrm{a}$ & $11.87 \mathrm{de}$ & $13.67 \mathrm{~b}$ & $56.25 \mathrm{a}$ & $45.06 \mathrm{a}$ & $6.79 \mathrm{a}$ & $4.93 \mathrm{a}$ & $4.77 \mathrm{a}$ & $3.30 \mathrm{a}$ \\
\hline $\begin{array}{l}\text { Sour-sweet/ } \\
\text { centrifugation }\end{array}$ & $62.21 \mathrm{ab}$ & $48.55 \mathrm{bc}$ & $73.7 \quad \mathrm{a}$ & 67.6 & $12.34 \mathrm{~cd}$ & $13.72 \mathrm{~b}$ & $53.92 \mathrm{a}$ & $44.17 \mathrm{a}$ & $6.36 \mathrm{ab}$ & $4.91 \mathrm{a}$ & $4.35 \mathrm{ab}$ & $3.21 \mathrm{a}$ \\
\hline $\begin{array}{l}\text { Sweet/ } \\
\text { squeezing }\end{array}$ & $61.5 \mathrm{ab}$ & $45.8 \mathrm{c}$ & $60.19 \mathrm{a}$ & $42.61 \mathrm{~d}$ & $11.56 \mathrm{e}$ & $13.52 \mathrm{~b}$ & $26.33 \mathrm{~d}$ & $19.94 \mathrm{~d}$ & $4.34 \mathrm{f}$ & $3.154 \mathrm{c}$ & $2.28 \mathrm{~d}$ & $1.48 \mathrm{c}$ \\
\hline $\begin{array}{l}\text { Sweet/ } \\
\text { centrifugation }\end{array}$ & $69 \quad \mathrm{a}$ & $54.8 \quad a b$ & $68.40 \mathrm{bc}$ & $62.12 \mathrm{abc}$ & $11.57 \mathrm{e}$ & $13.09 \mathrm{~b}$ & $43.07 \mathrm{c}$ & $38.07 \mathrm{ac}$ & $5.93 \mathrm{bc}$ & $4.75 \mathrm{ab}$ & $3.73 \mathrm{bc}$ & $2.91 \mathrm{ab}$ \\
\hline Local Juice & $64.18 \mathrm{ab}$ & $50.01 \mathrm{ab}$ & $72.05 \mathrm{a}$ & $64.99 \mathrm{ab}$ & $15.12 \mathrm{a}$ & $15.33 \mathrm{a}$ & $53.09 \mathrm{ab}$ & $41.65 \mathrm{ab}$ & $5.1 \mathrm{de}$ & $4.24 \mathrm{~b}$ & $3.51 \mathrm{c}$ & $2.72 \mathrm{ab}$ \\
\hline
\end{tabular}

The values are average of five numbers.

Different letters in the same column means there are significant $(\mathrm{P}<0.05)$ differences. 
Mesopotamia J. of Agric.

Vol. (42) No. (1) 2014
ISSN: 2224-9796 (Online)

ISSN: 1815-316 X (Print)

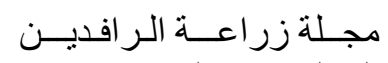

المجلد (42) العدد (1) 2014 المرن

LDL-C may be related to the presence of different polyphenolic compounds with other compounds such as ascorbic acid which collectively responsible for protective and antioxidative effects (Gerster, 1999) and reduces oxidative stress (Gey, 1995; Rock et al., 1996, Nagyova, 1998) and reduces oxidative stress, atherogenic modifications to LDL, and platelet aggregation (Aviram et al., 2000 ).

Results show that there were a significant $(\mathrm{P}<0.05)$ differences between atherogenic factors as TC/HDL-C or LDL-C/HDL-C for the animals gavaged with different pomegranate juices extracted by squeezing and centrifugation methods including control animals. Atherogenic factors as TC/HDL-C and LDL-C/HDL-C ranged between 2.58 to 4.93 and 0.72 to 3.30 , respectively for all animals gavaged with different pomegranate juices. Comparing the values of TC/HDL-C or LDL-C/HDL-C after 28 days of experiment we found that the values were significantly $(\mathrm{P}<0.05)$ decreased for all groups of animals gavaged with pomegranate juices including control group.

Results also show that the atherogenic factor of LDL-C/HDL-C decreased to lower value $(0,721)$ for animals gavaged with sour pomegranate juice extracted by squeezing method but similar to that of control group. Other decreased little to values of 3.30 and 3.21 for those animals gavaged with sour sweet pomegranate juice extracted by squeezing method and centrifugation method, respectively. Finally, data in table (3) show that all pomegranate juices used in this studies show a decreasing in TG, TC, TC/ HDL-C and LDL-C/ HDL-C and increasing in HDL-C in which indicating an improvement of lipid profile and may attenuation of atherosclerosis development in healthy rats and this was in agreement with those found by Yousif (2000). Aviram et al. (2000) found that consumption of pomegranate juice by healthy subjects decreased LDL-C susceptibility to aggregation and retention by inhibiting atherogenic modifications of LDL, including its retention, oxidation, and aggregation and also increased the activity of serum paraoxonase (an HDL-associated esterase that can protect against lipid peroxidation). The antiatherogenic effect of pomegranate juice have been attributed to its wide range of phytochemicals, which are predominantly polyphenols, including primarily hydrolyzable ellagitannins, anthocyanins, and other polyphenols and organic acid such as ascorbic acid which possess potent antioxidative properties. (Aviram and Dornfeld, 2001 and ViudaMartos et al., 2010a). Other suggestions may be by increasing serum antioxidant activity and decreasing plasma lipids and lipid peroxidation (Basu and Penugonda, 2009).

The effect of pomegranate juices extracted by squeezing and centrifugation methods in hypercholesterolemic rats was shown in Table (4). Results show that there were significant $(\mathrm{p}<0.05)$ differences between the final TG values in hypercholesterolemic animals after 28 days of gavaged with different pomegranate juices compared with control group. The TG values were ranged between $59.93 \mathrm{mg} / 100 \mathrm{ml}$ for animals gavaged with sour sweet pomegranate juice extracted by squeezing method and $78.14 \mathrm{mg} / 100 \mathrm{ml}$ for animals gavaged with commercial pomegranate juice compared with 75.50 for control group. When comparing the levels of TG after 28 days of experiment we found that the levels were decreased for all groups of animals gavaged with pomegranate juices compared with control group. The TG value was decreased from 80.31 to $60.34 \mathrm{mg} / 100 \mathrm{ml}$ for animals gavaged with sour pomegranate juice extracted by squeezing method compared with lowest decreased (81.23 to $78.14 \mathrm{mg} / 100 \mathrm{ml}$ ) for animals gavaged with commercial pomegranate juice.

Results also show that there were significant $(\mathrm{P}<0.05)$ differences between the TC values for hypercholesterolemic animals gavaged with different pomegranate juice. The lowest 
Mesopotamia J. of Agric.

Vol. (42) No. (1) 2014
ISSN: 2224-9796 (Online)

ISSN: 1815-316 X (Print)

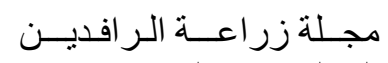

المجلد (42) العدد(1) 2014 العراعن

TC value was $74.42 \mathrm{mg} / 100 \mathrm{ml}$ for animals gavaged with sour pomegranate juice extracted by squeezing method compared with $125.41 \mathrm{mg} / 100 \mathrm{ml}$ for control animals. Comparing the levels of TC after 28 days of experiment we found that the levels were decreased for all groups of animals gavaged with pomegranate juices compared with control group. The TC value was decreased from 130.04 to $74.42 \mathrm{mg} / 100 \mathrm{ml}$ for animals gavaged with sour pomegranate juice extracted by squeezing method followed by animals gavaged with sweet pomegranate juice extracted by squeezing method. Esmaillzadeh et al. (2006) studied the effect of concentrated pomegranate juice on lipid profiles of diabetic (type II) and hyperlipidemia patients after 8 weeks of experiment. They showed reductions in TC, LDL cholesterol, TC/HDL-C ratio and LDL/HDL ratio. But there were no significant changes in serum triacylglycerol and HDL-c concentrations.

Table $(4)$ shows that there were significant $(\mathrm{P}<0.05)$ differences between HDL-C values for rats gavaged with different pomegranate juices. Results show that the lowest HDL-C value was $10.5 \mathrm{mg} / 100 \mathrm{ml}$ for control animals and the highest value of 14.76 $\mathrm{mg} / 100 \mathrm{ml}$ for animals gavaged with sour pomegranate juice extracted by squeezing method followed by $13.91 \mathrm{mg} / 100 \mathrm{ml}$ for group gavaged with sour sweet pomegranate juice extracted by squeezing method. Comparing the HDL-C values after 28 days of experiment we found that the levels were increased for all groups of animals gavaged with pomegranate juices compared with control group. The increased of HDL-C value was ( 10.6 to $14.76 \mathrm{mg} / 100 \mathrm{ml}$ ) for animals gavaged with sour pomegranate juice extracted by squeezing method and the lowest change was $(10.98$ to $12.44 \mathrm{mg} / 100 \mathrm{ml})$ for group of animals gavaged with commercial pomegranate. Kolovou et al. (2005) stated that an inverse correlation between fasting TG and HDL-C levels was found among dyslipidemic untreated patients and their relationship remains stable in all patients' phenotypes and indirectly implies that TG and HDL-C levels depend on common metabolic pathways and this correlation should be taken into consideration when the risk of atherosclerosis is evaluated.

The data of Table $(4)$ also show significant $(\mathrm{P}<0.05)$ differences between $L D L-C$ values of animals gavaged with different pomegranate juices compared with control group. LDL$\mathrm{C}$ values were ranged between the lowest value of $50.36 \mathrm{mg} / 100 \mathrm{ml}$ for animals gavaged with sour sweet pomegranate juice extracted by squeezing method and $99.67 \mathrm{mg} / 100 \mathrm{ml}$ for group of animals gavaged with commercial pomegranate juice compared with 99.10 $\mathrm{mg} / 100 \mathrm{ml}$ for control animals. However, when we compare the LDL-C values after 28 days of experiment we found that the levels were highly decreased for all groups of animals gavaged with pomegranate juices compared with control group. For example, the values were decreased from 103.39 to $53.61 \mathrm{mg} / 100 \mathrm{ml}$ for animals gavaged with sour pomegranate juice extracted by squeezing method and from 105.02 to $50.36 \mathrm{mg} / 100 \mathrm{ml}$ for group gavaged with sour sweet pomegranate extracted by squeezing method and from 108.62 to $53.61 \mathrm{Mg} / 100 \mathrm{ml}$ for animals gavaged with sweet pomegranate juice extracted by squeezing method compared withdecreasing of the LDL-C value from 104.25 to 99.1 $\mathrm{mg} / 100 \mathrm{ml}$ for control group. 
Mesopotamia J. of Agric.

Vol. (42) No. (1) 2014
ISSN: 2224-9796 (Online)

ISSN: $1815-316 \mathrm{X}$ (Print)
مجـلـة زر اعسـة الر افديـنـن المجلد (42) العدد(1) 2014 ألران

Table (4): Effect of pomegranate juice extracted by squeezing and centrifugation on lipid profile in hypercholesterolemic rats $(\mathrm{mg} / 100 \mathrm{ml})$.

\begin{tabular}{|c|c|c|c|c|c|c|c|c|c|c|c|c|}
\hline \multirow{2}{*}{ Juice } & \multicolumn{2}{|c|}{$\mathrm{TG}$} & \multicolumn{2}{|c|}{$\mathrm{TC}$} & \multicolumn{2}{|c|}{ HDL-c } & \multicolumn{2}{|c|}{ LDL-c } & \multicolumn{2}{|c|}{ TC/HDL-c } & \multicolumn{2}{|c|}{ LDL-c/HDL-c } \\
\hline & Initial & Final & Initial & Final & Initial & Final & Initial & Final & Initial & Final & Initial & Final \\
\hline Control & 77.05 abcd & $75.50 \mathrm{a}$ & $129.41 \mathrm{~b}$ & $125.412 \mathrm{a}$ & 9.75 abcd & $10.500 \mathrm{~d}$ & $104.25 \mathrm{bc}$ & $99.103 \mathrm{a}$ & $13.678 \mathrm{~b}$ & $12.2621 \mathrm{a}$ & $11.045 \mathrm{~b}$ & $9.7056 \mathrm{a}$ \\
\hline $\begin{array}{l}\text { Sour/ } \\
\text { squeezing }\end{array}$ & $80.31 \quad a b$ & $60.34 \mathrm{~b}$ & $130.04 \mathrm{~b}$ & $74.418 \mathrm{~d}$ & $10.596 \mathrm{ab}$ & $14.7600 \mathrm{a}$ & $103.39 \mathrm{bc}$ & $53.608 \mathrm{~cd}$ & $12.367 \mathrm{~b}$ & $4.974 \mathrm{e}$ & $9.847 \mathrm{~b}$ & $3.1364 \mathrm{f}$ \\
\hline $\begin{array}{l}\text { Sour/ } \\
\text { centrifugation }\end{array}$ & 79.17 abc & $64.22 \mathrm{~b}$ & $121.1 \mathrm{bc}$ & $92.00 \mathrm{bc}$ & 9.864 abcd & $13.388 \mathrm{abc}$ & $95.36 \mathrm{bc}$ & $65.768 \mathrm{bc}$ & $12.548 \mathrm{~b}$ & $6.8879 \mathrm{~cd}$ & $9.932 \mathrm{~b}$ & $4.9269 \mathrm{~cd}$ \\
\hline $\begin{array}{l}\text { Sour-sweet/ } \\
\text { squeezing }\end{array}$ & $76.93 \mathrm{abcd}$ & $59.93 \mathrm{~b}$ & $130.75 \mathrm{~b}$ & $76.246 \mathrm{~d}$ & $10.35 \mathrm{abc}$ & $13.9100 \mathrm{ab}$ & $105.02 \mathrm{bc}$ & $50.350 \mathrm{~d}$ & $12.903 \mathrm{~b}$ & $5.4742 \mathrm{de}$ & $10.388 \mathrm{~b}$ & $3.6104 \mathrm{ef}$ \\
\hline $\begin{array}{l}\text { Sour-sweet/ } \\
\text { centrifugation }\end{array}$ & $74.50 \mathrm{~cd}$ & $62.50 \mathrm{~b}$ & $102.66 \mathrm{c}$ & $75.132 \mathrm{~d}$ & $8.950 \mathrm{~d}$ & $12.052 \mathrm{c}$ & $78.81 \mathrm{c}$ & $50.580 \mathrm{~d}$ & $11.523 \mathrm{~b}$ & $6.2301 \mathrm{cde}$ & $8.850 \mathrm{~b}$ & $4.1911 \mathrm{cdef}$ \\
\hline $\begin{array}{l}\text { Sweet/ } \\
\text { squeezing }\end{array}$ & $73.20 \mathrm{~d}$ & $60.246 \mathrm{~b}$ & $132.67 \mathrm{~b}$ & $79.018 \mathrm{~cd}$ & $9.412 \mathrm{ccd}$ & $13.3640 \mathrm{abc}$ & $108.62 \mathrm{~b}$ & $53.608 \mathrm{~cd}$ & $14.135 \mathrm{ab}$ & $5.9397 \mathrm{de}$ & $11.577 \mathrm{~b}$ & $4.035 \mathrm{def}$ \\
\hline $\begin{array}{l}\text { Sweet/ } \\
\text { centrifugation }\end{array}$ & $75.18 \mathrm{~cd}$ & $65.18 \mathrm{~b}$ & $120.83 \mathrm{bc}$ & $94.022 \mathrm{~b}$ & $8.740 \mathrm{~d}$ & $12.7380 \mathrm{bc}$ & $97.01 \mathrm{bc}$ & $68.248 \mathrm{~b}$ & $13.940 \mathrm{ab}$ & $7.3868 \mathrm{c}$ & $11.203 \mathrm{~b}$ & $5.3603 \mathrm{c}$ \\
\hline Local Juice & $81.23 \mathrm{a}$ & $78.14 \mathrm{a}$ & $138.05 \mathrm{ab}$ & $127.740 \mathrm{a}$ & $10.982 \mathrm{a}$ & $12.444 \mathrm{bc}$ & $110.82 \mathrm{~b}$ & $99.668 \mathrm{a}$ & $12.581 \mathrm{~b}$ & $10.2867 b$ & $10.101 \mathrm{~b}$ & $8.0299 \mathrm{~b}$ \\
\hline
\end{tabular}

The numbers are represented of five animals>

Different letters in the same column means there are significant $(\mathrm{P}<0.05)$ differences. 
Anoosh et al. (2010) found that pomegranate juice possess impressive antioxidative properties in which their results indicated that LDL-C in hypercholesterolemic patients showed a significant decrease at $p<0.01$ after consumption of two varieties of pomegranate juices comparing with a drug (lovstatin) and showed no difference between two groups with drug group.

Results show that consumption of different pomegranate juices by hypercholesterolemia rats resulted in decreasing of TG, TC, LDL-C, TC/HDL-C and LDL-C/HDL-C and increasing HDL-C values compared with control group. This finding was in agreement with these finding by Carbonaro et al. (1996); Rock et al. (1996) and Tebib et al. (1997). Feeding hypercholesterolemic rats on basal diet containing pomegranate peel extract at different levels obviously reduced $(\mathrm{P}<0.05)$ the levels of TC, TG and TL in rats serum by rates from $41.1-52.1 \%$ as compared to control group (28.6-30.2\%) (Ibrahium, 2010).And this may be due to its wide range of phytochemicals, which are predominantly polyphenols, including primarily hydrolyzable ellagitannins, anthocyanins, and other polyphenols and organic acid such as ascorbic acid which possess potent antioxidative properties against radical groups (Aviram and Dornfeld, 2001 and Viuda-Martos et al., 2010a). Kaplan et al. (2001) stated that pomegranate juice supplementation to mice with advanced atherosclerosis reduced their macrophage oxidative stress, their macrophage cholesterol flux and even attenuated the development of atherosclerosis.

\title{
تأثير عصير الرمان في الثوابت الدهنية لاى الجرذان السليمة وفرط الكوليسترول

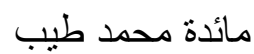

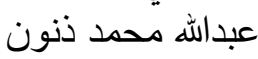

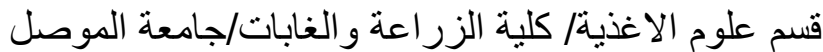 \\ E-mail:dr_thannoun@yahoo.Com
}

\begin{abstract}
بالخلاصة
تم دراسة تأثير عصير الرمان المستخلص بالعصر والنبذ على الثوابت الدهنية لدي الجرذان الثران السليمة

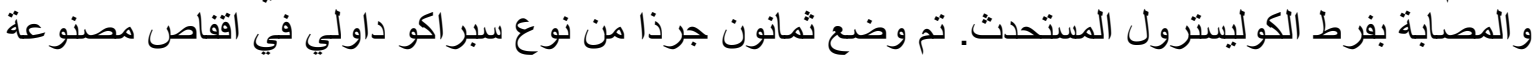

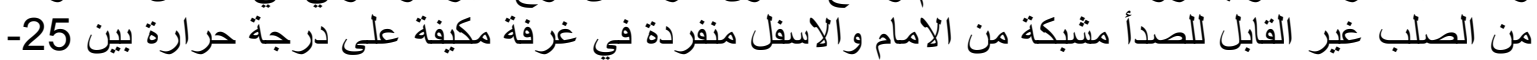

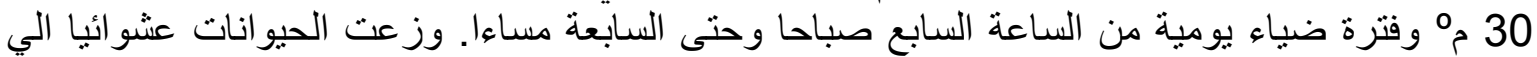

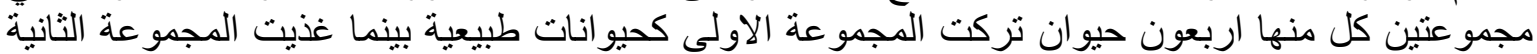

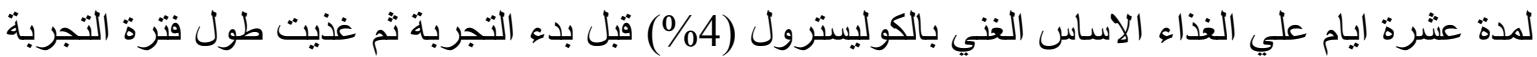

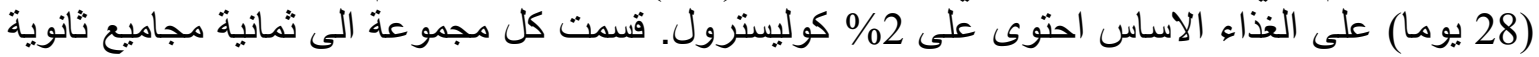
كل منها خمسة حيو انات تم تجريعا 1 مل من عصير الرمان الزئ المختلف عدا مجمو عتي السيطرة و التي اعطيت

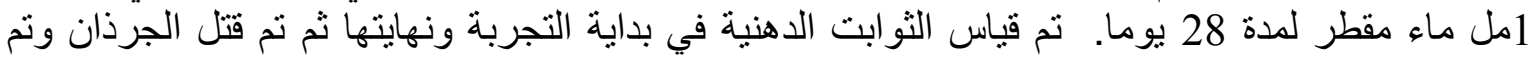

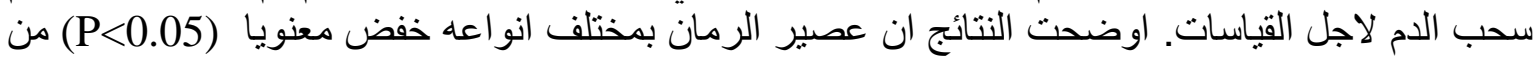

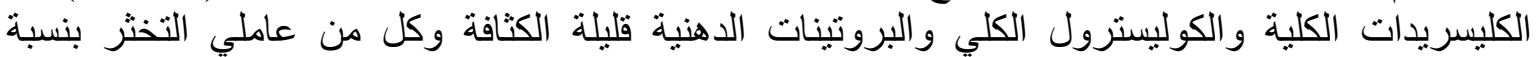

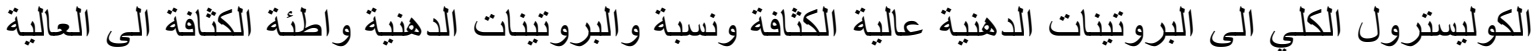

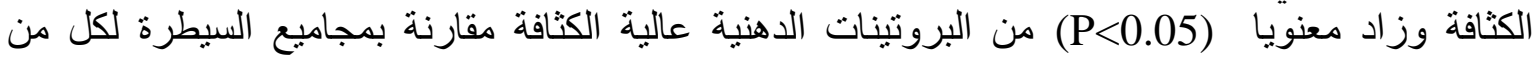

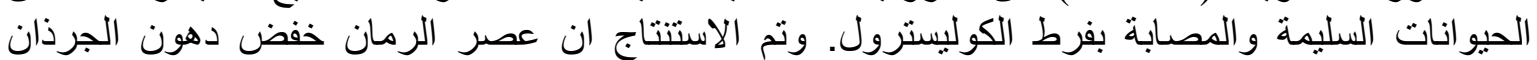

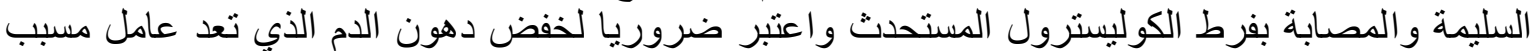
خطورة تصلب الثر ايين. كلمات الدالة:- عصير الرمان، طرق الاستخلاص، الثوابت الدهنية، جرذان.
\end{abstract}


Mesopotamia J. of Agric.

Vol. (42) No. (1) 2014

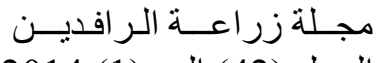

المجلد (42) العدد(1) 2014

\section{REFERENCES}

A Review. Alternative Medical Review, 13(2):128-144.

Aarabi, A.; M. Barzegar and M. H. Azizi (2008). Effect of cultivar and cold storage of pomegranate (Punica granatum L.) juices on organic acid composition. ASEAN Food Journal, 15 (1): 45-55.

Anonymous (1978). National Academy of Science-National Research Council (NAS/NRC). Nutrient requirement of laboratory animals. 3rd Ed. No. 10 Washington DC, USA.

Anonymous (2000). Association of Official Analytical Chemists (AOAC). Official Methods of Analysis, $13^{\text {th }}$ Ed., Washington, DC.

Anoosh, E.; E. Mojtaba and S. Fatemeh (2010). Study the effect of juice of two variety of pomegranate on decreasing plasma LDL cholesterol. Procedia Social and Behavioral Sciences, 2 (2): 620-623.

Aviram, M. and L. Dornfeld (2001). Pomegranate juice consumption inhibits serum angiotensin converting enzyme activity and reduces systolic blood pressure. Atherosclerosis, 158 (1): 195-198.

Aviram, M., L. Dornfeld, M. Rosenblat, N. Volkova, M. Kaplan, R. Coleman, T. Hayek, D. Presser and B. Fuhrman (2000). Pomegranate juice consumption reduces oxidative stress, atherogenic modifications to LDL, and platelet aggregation: studies in humans and in atherosclerotic apolipoprotein Edeficient mice. American Journal of Clinical Nutrition, 71(5): 1062-1076.

Aviram, M.; L. Dornfeld; M. Kaplan; R. Coleman; D. Gaitini; S. Nitecki; A. Hofman; M. Rosenblat; N. Volkova; D. Presser (2002). Pomegranate juice flavonoids inhibit low-density lipoprotein oxidation and cardiovascular diseases: studies in atherosclerotic mice and in humans. Drugs Experiment and Clinical Research, 28:49-62.

Basu A. and K. Penugonda (2009). Pomegranate juice: a heart-healthy fruit juice. Nutrition Review, 67(1):49-56.

Carbonaro, M. F. Virgili and E.Carnovale (1996). Evidence for protein-tannin interaction in legumes-implications antioxidant properties of feba bean tannins. Food Science and Technology-Lebensmittel-wissenschaft and Technologie, 29(8): 743-750.

Clifford, M. N. and A. Scalbert (2000). Ellagitannins-nature, occurrence and dietary burden. Journal of Science and Food Agriculture, 80:1118-25.

Ekşi, A. I. Ozhamamc (2009). Chemical composition and guide values of pomegranate juice. GIDA, 34 (5): 265-270.

El Kar, C.; A. Ferchichi; F. Attia and J. Bouajila (2011). Pomegranate (Punica granatum) Juices: Chemical Composition, Micronutrient Cations, and Antioxidant Capacity. Journal of Food Science, 76: C795-C800.

EL-Nemr, S. E.; I. A. Ismail and M. Ragab (1990). Chemical composition of juice and seeds of pomegranate fruit. Die Nahrung, 34 (7): 60-606.

Elzbieta, M. K.; J. David Spence; J. John; W. Stephen; J. F. David; A. P. Leonard and S. Paula (2000). HDL- cholesterol- raising effect of orange juice in subjects with hypercholesterolemia. American Journal Clinical Nutrition, 72, (5): 1095-1100.

Esmaillzadeh A; F. Tahbaz; I. Gaieni; H. Alavi-Majd and L. Azadbakht (2004). Concentrated pomegranate juice improves lipid profiles in diabetic patients with hyperlipidemia. Journal of Medicinal Food, 7(3):305-8. 
Fadavi, A., Barzegar, M., Azizi, M.H. and Bayat, M. (2005). Physicochemical composition of ten pomegranate cultivars (Punica granatum L.) grown in Iran. Food Science and Technology International, 11: 113-119.

Folch, J.; M. Lees; G. H. Sloane Stanley (1957). A simple method for the isolation and purification of total lipids from animal tissues. Journal of Biological Chemistry, 226: 497-509.

Gerster, H. (1999). High-dose vitamin C: A risk for persons with iron stores. International Journal of Vitamin Nutrition Research, 69(2):67-82.

Gey, K. F. (1995). Ten-Year retrospective on the antioxidant hypothesis of arteriosclerosis-thershold plasma levels of antioxidant micronutrient related to minimum cardiovascular risk. Journal of Nutritional Biochemistry, 6(4): 206236.

Gil M.I; F. A. Tomas-Barberan; B. Hess-Pierce; D.M Holcroft and A.A. Kader (2000). Antioxidant activity of pomegranate juice and its relationship with phenolic composition and processing. Journal of Agriculture and Food Chemistry, 48 (10):4581-4589.

Glew, R. H. and S.P. Peters (1987). Clinical Studies in Medical Biochemistry. pp 259. Oxford University Press, Madison Avenue, New York.

Ibrahium, M. I. (2010). Efficiency of Pomegranate Peel Extract as Antimicrobial, Antioxidant and Protective Agents. World Journal of Agricultural Sciences, 6 (4): 338-344.

Jurenka, J. (2008). Therapeutic Applications of Pomegranate (Punica granatum L.):

Kaplan, M; T. Hayek; A. Raz; R. Coleman; L. Dornfeld; J. Vaya and M. Aviram (2001). Pomegranate Juice Supplementation to Atherosclerotic Mice Reduces Macrophage Lipid Peroxidation, Cellular Cholesterol Accumulation and Development of Atherosclerosis. Journal of Nutrition, 131(8): 2082-2089.

Kolovou, G. D.; K. Anagnostopoulou; N. D. Pilatis; K. D. Salpea; I. S. Hoursalas; I. Petropoulos; H. I. Bilianou and D. V. Cokkinos (2005). Fasting serum triglyceride and high-density lipoprotein cholesterol levels in patients intended to be treated for dyslipidemia. Vascular Health and Risk Management, 1(2): $155-161$.

Lansky E.P. and R. A. Newman (2007). Punica granatum (pomegranate) and its Malik A.; A. Afaq; S. Sarfaraz; V. M. Adhami; D. N. Syed and H. Mukhtar (2005).

Miguel G.; S. Dandlen; D. Antunes; A. Neves and D. Martins (2004). The Effect of Two Methods of Pomegranate (Punica granatum L) Juice Extraction on Quality During Storage at $4^{\circ}$ C. Journal of Biomedical Biotechnology, 5 (1): 332-337.

Nagyova, A. M. Kuldlakova; E.Grancicova and T. Magalova (1998). LDL oxidizability and antioxidant status of plasma in vegetarians. Annual Nutrition Metabolism, 42(6):328-332.

Pomegranate fruit juice for chemoprevention and chemotherapy of prostate cancer. PNAS, 102:14813-14818.

potential for prevention and treatment of inflammation and cancer. Journal of ethnopharmacology, 109 (2): 177-206.

Seeram, N. P., S. M. Henning, Y. Zhang, M. Suchard, Z. Li and D. Heber (2006). Pomegranate Juice Ellagitannin Metabolites Are Present in Human Plasma and Some Persist in Urine for Up to 48 Hours. Journal of Nutrition, 136 (10): 2481-2485.

Steel, R. G. D. and J. H. Torrei (1980). Analysis of Principles and Procedures of Statistics. $2^{\text {nd }}$ Ed. McGraw Hill, N.Y, USA. 
Sumner, M. D.; M. Elliott-Eller; G. Weidner; J. J. Daubenmier; M. H. Chew; R. Marlin; C. J. Raisin and D. Ornish (2005). Effects of pomegranate juice consumption on myocardial perfusion in patients with Coronary Heart Disease. American Journal of Cardiology, 96:810-814.

Tebib, K. J. M. Rouanet and P. Besancon (1997). Antioxidant effect of dietary polymeric grape seed tannins in tissue of rats fed a high cholesterol vitamin E-deficient diet. Food Chemistry, 59(1):135-141.

Thannoun, A. M. and M. M. Tayib (in press). Chemical composition and some charactreistics of pomegranate juice extracted by squeezing and centrifugation methods. Mesopotamia Journal of Agriculture.

Tietz N. W. (1987). Fundamental of Clinical Chemistry. PP. 469-478, $3^{\text {rd }}$ Ed Saunders, USA.

Viuda-Martos M.; Y. Ruiz-Navajas; A. Martin-Sánchez; E Sánchez-Zapata; J. Fernández-López; E. Sendra; E. Sayas-Barberá; C. Navarro and J. A. PérezÁlvarez (2010b). Chemical, physico-chemical and functional properties of pomegranate (Punica granatum L.) bagasse powder co-product. International Conference on Food Innovation 25-29 October, Food Innovation 2010, 1-4.

Viuda-Martos, M.; J. Fern'andez-L'opez and J.A. P'erez-'Alvarez (2010a). Pomegranate and its Many Functional Components as Related to Human Health: A Review. Comprehensive Reviews In Food Science and Food Safety, 9: 635-654.

Yousif, S.M.A. (2000). Clinical evaluation of the lipid regulating activity of the aqueous extract of walnut leaves in hyperlipidemic patients. M. Sc. Thesis, College of Pharmacy. University of Mosul, Iraq. 